\title{
REVISTA DE FILOSOFIA AURORA
}

A presente publicação foi fundada em 1988 com o nome de Revista de Filosofia da PUCPR com o intuito de constituir um canal aberto para divulgação da pesquisa em filosofia, especialmente da produção local e sem a preocupação com a adoção de focos temáticos. No entanto, a partir de 1998, o Curso de Filosofia da PUCPR passou a exigir uma maior qualificação de sua produção intelectual, principalmente em função do amadurecimento de grupos de pesquisa e do diálogo com outros centros de pesquisa em filosofia. Tais mudanças repercutiram na revista, que passou por um amadurecimento, desde a reestruturação do comitê editorial passando pela rigorosa seleção dos artigos, predominantemente de pesquisadores externos à PUCPR. Tal amadurecimento, no qual a revista teve, por sua vez, importante papel, culminou na apresentação de um projeto de Mestrado em Filosofia aprovado pela CAPES em 2003. Por conta disso, as atividades do mestrado, que tiveram início em 2004, especialmente aquelas ligadas aos projetos de pesquisa que se desenvolvem em conjunto com pesquisadores de outras instituições, não somente impulsionaram a revista, como a levaram, a partir de 2005, a se desdobrar como atividade editorial conjunta da PUCPR e da PUC-SP.

Neste ponto, a Revista ampliou ainda mais seu propósito inicial, para apresentar-se como um canal de divulgação da pesquisa de qualidade em filosofia aberto não apenas para a comunidade filosófica local, mas de todo o país e do exterior, oferecendo para essa mesma comunidade diferentes tipos de produção bibliográfica como, dossiês, artigos diversificados, resenhas, ensaios e resumos de dissertações.

Felizmente a sequência de sua evolução não parou por aqui, tendo atingido seu ápice a partir do segundo semestre de 2006 pela combinação de dois fatores, a saber: a rearticulação das produções classificadas sob a rubrica de dossiê e fluxo-contínuo, além de resenhas; a revisão de seu layout e diagramação, inclusive ganhando versão eletrônica.

No início de 2008, a Revista de Filosofia Aurora, por meio de suas novas políticas de publicação, tornou-se referência no cenário filosófico nacional. Isso também foi confirmando a partir da abertura do Doutorado em Filosofia na PUCPR, no ano de 2012, fato que representou um novo passo no esforço qualitativo que tem marcado a trajetória do periódico. Atualmente, a Revista de Filosofia Aurora, tem procurado estreitar os laços entre as políticas adotadas pelos indexadores e o contato com diversas universidades estrangeiras com o objetivo de internacionalizar cada vez mais o periódico.

Editores 